\title{
Northern Australian pasture and beef systems. 1. Net carbon position
}

\author{
Steven Bray ${ }^{\mathrm{A}, \mathrm{D}}$, Natalie Doran-Browne ${ }^{\mathrm{B}}$ and Peter O' Reagain ${ }^{\mathrm{C}}$ \\ ADepartment of Agriculture, Fisheries and Forestry, PO Box 6014, Rockhampton, Qld 4702, Australia. \\ ${ }^{B}$ Melbourne School of Land and Environment, The University of Melbourne, Vic. 3010, Australia. \\ ${ }^{C}$ Department of Agriculture, Fisheries and Forestry, PO Box 976, Charters Towers, Qld 4820, Australia. \\ ${ }^{D}$ Corresponding author. Email: steven.bray@daff.qld.gov.au
}

\begin{abstract}
The beef industry in northern Australia manages $\sim 15$ million cattle, grazed on 250 million hectares of grassland and savanna woodland. The large size of the beef industry results in significant quantities of greenhouse gases being emitted to the atmosphere through ruminant livestock enteric methane production. However, livestock emissions are only one component of the carbon cycle in which grazing businesses operate. Livestock grazing also affects carbon stocks and fluxes in pasture, woody vegetation, soil and from fire through the consumption of forage and other landscape impacts. Little knowledge is available on the impact of different grazing management strategies on the 'net carbon position' incorporating carbon stocks and greenhouse gas emissions when grazing savanna woodlands. The Wambiana grazing trial in northern Queensland, Australia, provides an opportunity to assess carbon stocks and greenhouse gas emissions (reported

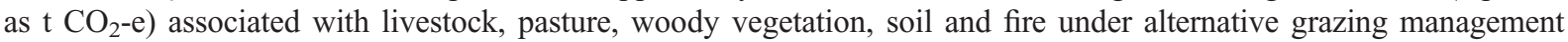
strategies (moderate and heavy stocking rate) over a 16-year period. The results indicate that tree biomass and woody vegetation dynamics dominate the carbon stocks and fluxes in grazed savanna woodlands. During the trial, both moderate and heavy stocking rate treatments had a positive net carbon balance, with the moderate stocking rate treatment having a better 'net carbon position' ( 19 t CO$_{2}$-e per ha) than the heavy stocking rate treatment ( $9 \mathrm{t} \mathrm{CO}_{2}$-e per ha), primarily due to less livestock emissions and greater pasture biomass and soil $\mathrm{C}$. These results add to the previously published benefits on land condition and economic return of grazing at moderate stocking rates, compared with heavy stocking rates.
\end{abstract}

Additional keywords: sequestration, sustainable grazing.

Received 29 May 2014, accepted 27 July 2014, published online 20 October 2014

\section{Introduction}

The northern Australian cattle industry operates across Queensland, the Northern Territory and northern Western Australia, grazing $\sim 15$ million head of cattle and utilising $~ 250$ million hectares of predominantly native grasslands, savannas, intact grassy woodlands and cleared woodlands (MLA 2013; ABS 2014). The large size of the industry means that community concern about significant environmental impacts is inevitable. Of primary concern is a decline in land condition leading to reduced water quality and sediment transport (e.g. Queensland Government 2013), impacts on biodiversity (Bastin 2008), and release of significant greenhouse gas emissions to the atmosphere (Charmley et al. 2008; Garnett 2009). Herd and grazing management changes are likely to be required to address or reduce the impact of these environmental issues. However, the highly variable climate, stagnant productivity growth, market issues and rising costs mean that most grazing businesses in northern Australia are struggling financially (McLean et al. 2014). Any proposed management change therefore needs to be carefully considered to assess impacts on profitability, productivity and environmental outcomes.
Australia's national greenhouse gas accounts indicate that livestock enteric fermentation is responsible for $\sim 10 \%$ of Australia's emissions (DIICCSRTE 2013). More than half of these emissions can be attributed to the northern cattle industry. The inherent biology of ruminants makes it difficult to reduce the daily enteric methane emissions from individual animals particularly when grazing extensive pasture with little or no supplementary feeding (Johnson and Johnson 1995; Charmley et al. 2008). The lack of direct abatement options means that management changes to reduce emissions must focus on improving herd efficiency by actions such as improving fertility so fewer cows are required, culling unproductive animals and increasing growth rates reducing the period until slaughter (Rolfe 2010; DAFF 2012; Cullen et al. 2013; Hristov et al. 2013).

Livestock emissions are however only one component of the carbon (C) and emissions cycles in which grazing businesses operate. Bray and Willcocks (2009) assessed the 'net C position' of the Queensland beef industry considering livestock, forage biomass, woody vegetation, soil $\mathrm{C}$, fire and fossil fuel energy emissions. They found that the livestock emissions were largely 
offset by biosequestration in the woody vegetation on grazing land following legislated restrictions on tree clearing and woodland thickening in remnant vegetation (Burrows et al. 2002). Property-scale analyses on four Queensland grazing properties found that livestock emissions could be offset with the retention and growth of a relatively small amount of additional trees with minimal impacts on livestock productivity (Bray and Golden 2009; Eady et al. 2011). These analyses were based on modelled data from a range of sources and necessarily had to include a range of assumptions such as herd structure, and cattle and tree growth rates. Few examples exist where most of the $\mathrm{C}$ stocks and fluxes and emissions calculations are based on actual measured data at a paddock or property scale.

The Wambiana grazing trial was established in 1997 in northern Queensland's savanna woodlands to assess grazing management options to cope with climate variability (O'Reagain et al. 2009). Results to date indicate that the moderate stocking rate (MSR) treatment has maintained land condition and had better financial returns with lower risk than the heavy stocking rate (HSR) treatment (O'Reagain et al. 2011; Scanlan et al. 2013). The Wambiana grazing trial provides an ideal opportunity to verify biophysical models (e.g. Scanlan et al. 2013; Doran-Browne et al. 2014) and assess the 'net C position', incorporating $\mathrm{C}$ stocks and greenhouse gas emissions of alternative grazing management options over a 16-year timeframe, since much of the data required has been measured within a rigorously designed grazing experiment (O'Reagain et al. 2009, 2011). This paper utilises the data from the Wambiana trial to assess and compare the net $\mathrm{C}$ position of the MSR and HSR treatments.

\section{Materials and methods}

\section{Wambiana grazing trial}

The Wambiana grazing trial was established near Charters Towers in north Queensland, Australia $\left(20^{\circ} 34^{\prime} \mathrm{S}, 146^{\circ} 07^{\prime} \mathrm{E}\right)$ to evaluate grazing management strategies for managing rainfall variability on extensive grazing properties (median property size in Central North Queensland is 39000 ha). Annual rainfall in this region is highly variable (range of 207-1409 $\mathrm{mm}$, mean $640 \mathrm{~mm}$ ) and strongly seasonal, with most rainfall $(\sim 70 \%)$ occurring in the summer months of December to March. Below-average rainfall was received at the trial between 2001 and 2006 (O'Reagain et al. 2011).

Three main land types based on soil type and woody vegetation associations occur at the site (O'Reagain et al. 2009):

(1) Box - moderately fertile brown sodosols and chromosols dominated by Reid River box (Eucalyptus brownii) occupying $\sim 55 \%$ of the area.

(2) Brigalow - more fertile grey earths and vertosols dominated by brigalow (Acacia harpophylla) occupying $~ 22 \%$ of the area.

(3) Ironbark - low fertility yellow/red kandosols dominated by silver-leaf ironbark (E. melanophloia) occupying 23\% of the area.

The 10 trial paddocks (93-115 ha) were fenced so that each paddock had roughly the same proportion of the three major land types. Five different stocking strategies were applied with two treatment replicates.
The greenhouse gas emissions and $\mathrm{C}$ stock assessment utilised data from the MSR and HSR treatments. The MSR treatment was stocked at $8-10$ ha/animal equivalent $(\mathrm{AE}=$ $450-\mathrm{kg}$ steer) and the HSR treatment was stocked at 4-5 ha/ AE (O'Reagain et al. 2009). For the present assessment each treatment 'paddock' was scaled to be 1000 ha, divided proportionally into the three main land types. We accessed the data for 16 years from 1997-98 to 2012-13. The first day of June was regarded as the start of each year, being notionally the start of the 6-month dry season and end of the 6-month wet season. The entire site was burnt in October 1999 and October 2011 to manage woodland thickening. All C stocks and greenhouse gas emissions were reported as carbon dioxide equivalents ( $\left.\mathrm{t} \mathrm{CO}_{2}-\mathrm{e}\right)$.

\section{Cattle emissions and biomass}

Treatments were stocked with one size class of cattle for the first 5 years with cattle changed annually at the end of the wet season. Thereafter, treatments had two cattle size classes, with a new batch of yearling steers $(\sim 360 \mathrm{~kg})$ being introduced annually and kept for 2 years, with approximately half the cattle replaced each year. See O'Reagain et al. $(2009,2011)$ for more detail.

For each treatment, herd records included livestock numbers and initial liveweight. Dry season liveweight gain and wet season liveweight gain were used to generate monthly livestock liveweights. An excel version of the FarmGAS calculator (http://www.farminstitute.org.au/calculators/farm-gas-calculator, verified 6 September 2014) was used to calculate yearly livestock greenhouse gas emissions (enteric methane and $\mathrm{N}_{2} \mathrm{O}$ emissions from livestock urine and faeces).

Average annual livestock biomass was calculated using the method of Bray and Willcocks (2009) assuming livestock were $40 \%$ dry matter and $50 \% \mathrm{C}$.

\section{Woody plant biomass and dynamics}

Live woody plant basal area was assessed four times in permanent 1-ha monitoring sites on the three main land types in the MSR and HSR paddocks, before and after the fire events in spring 1999 and 2011, using TRAPS woodland monitoring methodology (Back et al. 1997; Burrows et al. 2002). Between 1999 and 2011 live tree basal area increased by $8 \%$ and $7 \%$ in the MSR and HSR treatments respectively with no treatment differences detected. Data from the two treatments were combined for each land type. Monthly tree basal area was calculated over the life of the trial. Tree basal area change rates before the 1999 fire and after the post 2011 fire recordings were assumed to be at the same rate as the period between the two fires. Aboveground live tree biomass was estimated using the stand allometric of Burrows et al. (2002).

Currant bush (Carissa ovata) is a native, low sprawling shrub, which can impact grazing by displacing and competing for resources with forage plants (Back 2005). Currant bush cover was assessed on the permanent monitoring sites at the same time as the TRAPS tree basal area measurements, by measuring the proportion of the 500-m transect occupied by currant bush canopy. Treatment differences following the 1999 fire were detected with currant bush growth rates slower for the MSR than in the HSR treatment. Between 1999 and 2010 currant bush 
canopy increased by $23 \%$ and $82 \%$ in the MSR and HSR treatments respectively. Currant bush canopy change rates before the 1999 fire and after the post-2011 fire recordings were assumed to be the same rate as the period between the two fires. Monthly canopy area was calculated over the 16 years of the trial. Currant bush biomass was estimated by cutting 1050 by $50-\mathrm{cm}$ quadrats through the canopy, which yielded an average biomass of $10.7 \mathrm{t} / \mathrm{ha}$ of canopy.

\section{Forage and litter biomass and dynamics}

Total standing dry matter was assessed each year at the end of the wet season (May) using the BOTANAL procedure (Tothill et al. 1992), with 200 quadrat placements in each treatment replicate proportionally spaced across the three land types (O'Reagain et al. 2009). For each treatment, biomass and cumulative change in biomass $\left(\mathrm{t}_{2}\right.$-e $)$ from the start year 1997-1998 was calculated assuming the forage biomass was $50 \% \mathrm{C}$.

Litter biomass was measured in $0.25-\mathrm{m}^{2}$ quadrats during soil sampling in 2009 and $2010(n=395)$ across the two treatments and three land types. Litter biomass was assumed to have remained static throughout the trial period.

\section{Soil C stock and dynamics}

Soil C was sampled during three sampling campaigns in 2008, 2009 and 2010 (see Pringle et al. 2011; Allen et al. 2013; Segoli et al. 2014). Total organic soil $\mathrm{C}$ was assessed to a depth of $30 \mathrm{~cm}$ using a hydraulic driven push tube with samples analysed using dry combustion (see Pringle et al. 2011). Soil C measurements were conducted on average 12 years after the start of the trial. Pringle et al. (2011) found statistical differences and interactions between treatments and soil types. Averaging soil $\mathrm{C}$ differences across sampling campaigns, the MSR treatment had $20.3 \mathrm{t} \mathrm{C} /$ ha to $30-\mathrm{cm}$ depth compared with the HSR treatment with $19.2 \mathrm{t} \mathrm{C/hato} 30-\mathrm{cm}$ depth. Assuming the soil $\mathrm{C}$ stocks were similar at the start of the trial, it is impossible to know with certainty whether MSR has gained soil C, HSR has lost soil C or a combination of both. Being conservative we assume the MSR treatment has not gained soil C, but the HSR treatment has lost $1.05 \mathrm{t} \mathrm{C/ha} \mathrm{over}$ 12 years or $0.32 \mathrm{t} \mathrm{CO}_{2}$-e/ha.year due to the heavy grazing intensity.

\section{Coarse woody debris and standing dead trees}

Coarse woody debris (CWD) and standing dead tree biomass was assessed in the three land types in 2009 and assumed to have remained static throughout the trial period. CWD biomass was estimated by measuring the dimensions and calculating the volume of CWD greater than $2 \mathrm{~cm}$ diameter in two 100-m long, 1-m-wide belt transects in each land type. Sixty-nine pieces of CWD were subsequently collected covering the range of sizes encountered and dried at $45^{\circ} \mathrm{C}$ until constant weight was achieved. The volume of each piece was calculated based on the dimensions and shape. The relationship between volume and biomass (Eqn 1) was applied to the volume calculated in the belt transect and then converted to $\mathrm{CO}_{2}-\mathrm{e}$, assuming CWD biomass was $50 \% \mathrm{C}$.

$$
\begin{aligned}
\text { CWD biomass }(\mathrm{g})= & \text { Volume CWD }\left(\mathrm{cm}^{3}\right) \\
& \times 0.8225\left(R^{2}=0.94 ; n=69\right) .
\end{aligned}
$$

Standing dead trees were assessed in the three land types in 2009 using the Bitterlich technique (Grosenbaugh 1952). Standing dead tree biomass was estimated using the allometrics of Burrows et al. (2002).

\section{Energy use}

Emissions from energy use through fuel and electricity were not measured on the trial, but are of interest in the context of an operating grazing business. We applied on-farm energyrelated emissions of $0.009 \mathrm{t} \mathrm{CO}_{2}$-e/ha.year (Bray and Willcocks 2009; Eady et al. 2011).

\section{Fire emissions}

To account for the emissions from the 1999 and 2011 fire we used the Australian greenhouse accounts methodology (DIICCSRTE 2013) using the forage and litter biomass measured at the end of the wet season and a burn efficiency of 0.76 . The whole area was assumed to be burnt.

\section{Results}

Carbon stocks ranged from 223000 to $273000 \mathrm{t} \mathrm{CO}_{2}$-e/1000 ha during the 16 years of the trial and across the two stocking rate treatments (Fig. 1). Carbon in live trees and soil contributed on average $56 \%$ and $29 \%$ respectively to $\mathrm{C}$ stocks. The contribution from livestock biomass was small $(0.02 \%$ of the total). CWD, standing dead trees, forage and litter and currant bush contributed $\sim 15 \%$ to $\mathrm{C}$ stocks (Fig. 1).

Carbon fluxes and greenhouse gas emissions were dominated by the change in live-tree biomass (Fig. 2). This was driven by the two fire events, which reduced live tree biomass but was followed by tree growth in the inter-fire period. The 1999 fire occurred after a prolonged fire-free period and resulted in a large decline in live trees. In contrast, the second fire in 2011 had much less impact (Fig. 2). At the end of the analysis period in 2012/13 there was $21900 \mathrm{t} \mathrm{CO}_{2}$-e/1000 ha more live tree biomass than at the start of the trial indicating $\mathrm{C}$ sequestration.

The impact of climate cycles and interaction with grazing intensity can be observed in the forage and litter. In the MSR treatment, change in forage and litter biomass was slower to reach the maximum positive value (greatest emission) during the drought in the mid-2000s as on-ground forage biomass declined (Fig. 2). By the end of the trial period the MSR treatment had accumulated a small amount of $\mathrm{C}$ in the forage and litter compared with the start of the trial with $3 \mathrm{t} \mathrm{CO}_{2}-\mathrm{e} / \mathrm{ha}$ on average more biomass than the HSR treatment over the life of the trial.

Livestock emissions in the HSR treatment were greater than in the MSR treatment due to the higher livestock numbers. The HSR treatment had slightly lower fire emissions due to the lower fuel loads than the MSR treatment (Fig. 2). The difference in soil $\mathrm{C}$ between the two stocking rate treatments was attributed to the HSR treatment losing soil $\mathrm{C}$ equivalent to $4.8 \mathrm{t} \mathrm{CO}_{2}$-e/ha. By comparison, energy emissions were small with emissions of $0.14 \mathrm{t} \mathrm{CO}_{2}$-e/ha over 16 years. 


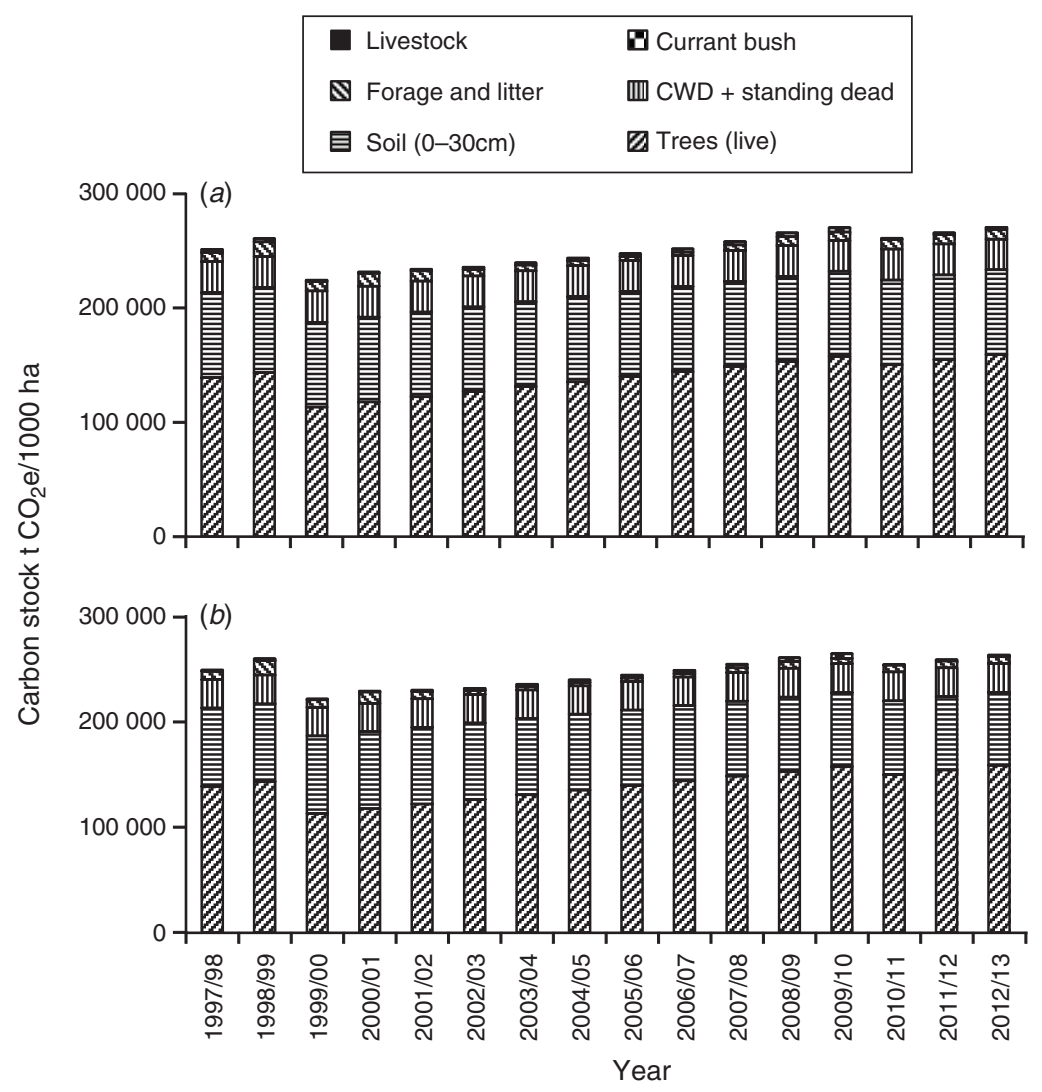

Fig. 1. Carbon stocks ( $\mathrm{t} \mathrm{CO}_{2}$-e per 1000 ha) for six biomass pools during the 16-year (1997-2013) Wambiana grazing trial for $(a)$ moderate stocking rate and $(b)$ heavy stocking rate treatments.

Combining the $\mathrm{CO}_{2}$-e fluxes over 16 years, indicated that the HSR and MSR treatments had a positive net $\mathrm{C}$ position of 8800 and 19100 t CO$_{2}$-e/1000 ha respectively (Fig. 3), with the majority of the difference due to forage and litter, livestock emissions and soil $\mathrm{C}$. The high variability during the experimental period largely associated with tree biomass change and to a lesser extent seasonal forage and litter biomass has implications for reference dates (we used the start of the trial in this assessment) for determining grazing industry greenhouse gas assessment baselines.

\section{Discussion}

Carbon in live trees dominated the $\mathrm{C}$ stocks and had the greatest dynamics in the present analysis (Figs 1,2). The C stocks in the live trees measured here were consistent with previous estimates for grazed woodlands (e.g. Burrows et al. 2002; Bray et al. 2006). The significant decline in live tree C following the fire in 1999 probably reflected the long period without fire before the Wambiana trial establishment, which resulted in an accumulation of older, hollow trees more susceptible to the fire. The second fire in 2011 had far less impact. Despite the fire-induced fluctuations, the trajectory of increasing $\mathrm{C}$ in live trees across land types observed here, often termed 'woodland thickening', has also been reported for other grazed woodlands (Burrows et al. 2002; Fensham et al. 2003;
Krull and Bray 2005; Bray et al. 2007; Krull et al. 2007). The woodland thickening observed at the trial appears to have been insensitive to grazing intensity over the 1997-2013 period.

Soil $\mathrm{C}$ was the second largest $\mathrm{C}$ stock at the site with the magnitude consistent with other soils in the region (e.g. Bray et al. 2006, 2010; Krull et al. 2007). There was variation in response of soil $\mathrm{C}$ to treatment between land types with the Box having higher soil $\mathrm{C}$ in the HSR treatment whereas the other two land types had higher soil C in the MSR treatment (Pringle et al. 2011). This inconsistency in the response of soil C to grazing intensity, land condition and land types has also been found in other studies in northern Australia (e.g. Bray et al. 2010). The average difference in soil $C$ between the MSR and HSR treatments ( $1.05 \mathrm{t} \mathrm{C/ha} \mathrm{over} 12$ years) was assumed to be due to a decline in the HSR treatment. Further long-term studies or validated soil $\mathrm{C}$ modelling are required to evaluate the ongoing direction and magnitude of soil $\mathrm{C}$ change in both treatments.

Forage and litter biomass was sensitive to grazing intensity, with lower forage and litter biomass in the HSR treatment. Ongoing heavy pasture utilisation in the HSR treatment is likely to further reduce the abundance and biomass of desirable 3P (productive, palatable and perennial) grasses whereas the proportion of annuals, unpalatable grasses and the exotic stoloniferous grass Bothrioichloa pertusa are increasing (O'Reagain and Bushell 2013; Doran-Browne et al. 2014). 

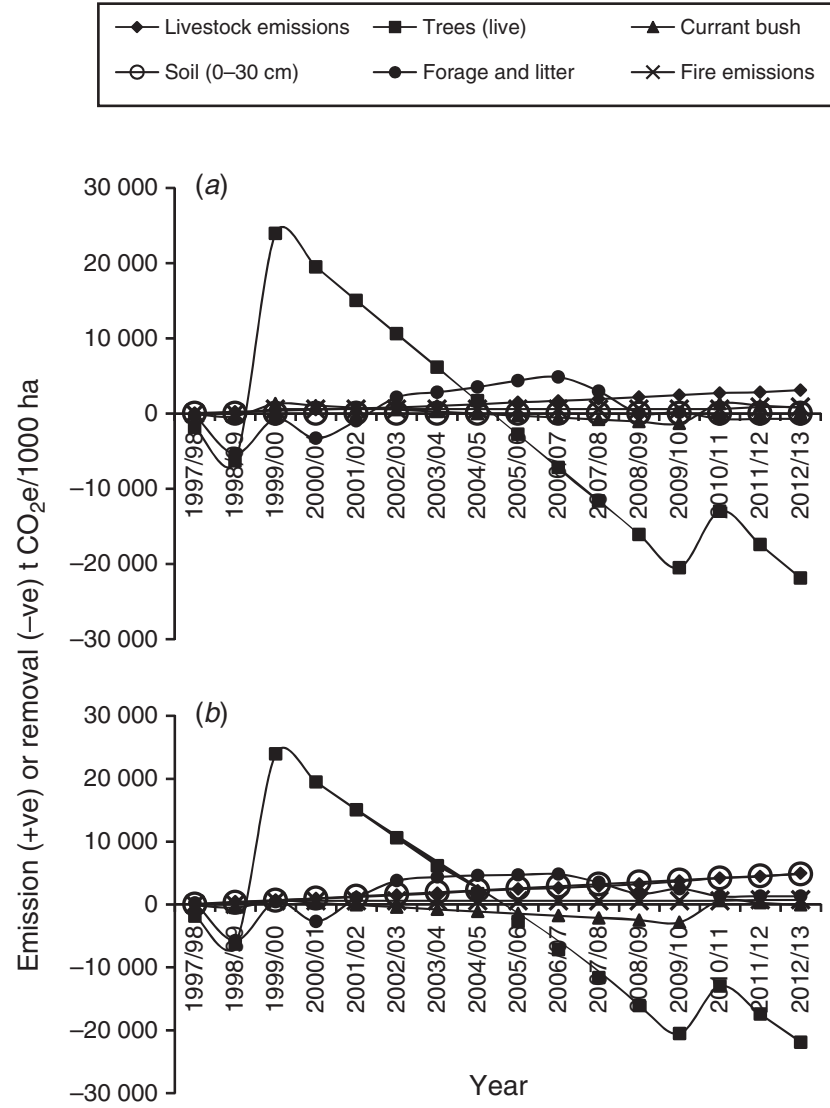

Fig. 2. Cumulative carbon fluxes and emissions ( $\mathrm{C}_{2}$-e per $\left.1000 \mathrm{ha}\right)$ during the 16-year (1997-2013) Wambiana grazing trial in (a) moderate stocking rate and $(b)$ heavy stocking rate treatments. Positive $(+v e)$ values indicate emission to the atmosphere and negative $(-v e)$ values indicate removal from the atmosphere relative to the starting year.

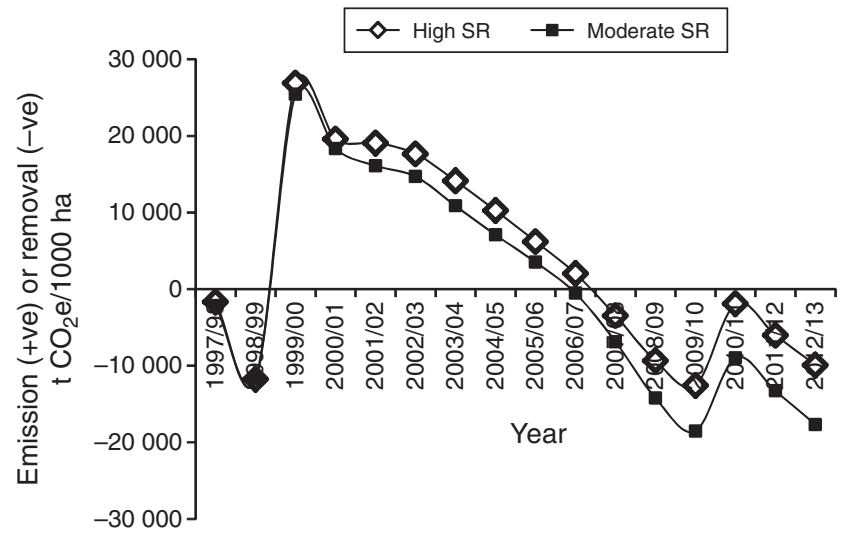

Fig. 3. Summary of the carbon flux and emissions ( $\mathrm{t} \mathrm{CO}_{2}$-e per $\left.1000 \mathrm{ha}\right)$ during the 16-year (1997-2013) Wambiana grazing trial in the heavy and moderate stocking rate treatments. Positive $(+v e)$ values indicate emission to the atmosphere and negative $(-\mathrm{ve})$ values indicate removal from the atmosphere relative to the starting year.

The overall future impact on soil and woody vegetation C stocks due to differences in land condition and fire intensity is still a matter of uncertainty. The lower soil $\mathrm{C}$ stocks in two of the three land types may provide an indication of declining soil $\mathrm{C}$ levels with reduced land condition and the decline in forage and litter biomass.

Currant bush (Carissa ovata) is a sprawling prickly shrub increasing in abundance in the Burdekin region (Grice et al. 2000). Regular fire has been shown to reduce the currant bush canopy area but has little impact on plant numbers (Back 2005). At Wambiana, currant bush cover has been increasing in both stocking rate treatments. However, the increase has been greater in the HSR treatment possibly in response to lower competition from forage and reduced fire intensity due to the lower fuel loads. Continued increase in currant bush will eventually decrease forage production and livestock carrying capacity, thereby reducing grazing productivity. Conversely, increasing currant bush may buffer $\mathrm{C}$ stock losses through maintaining $\mathrm{C}$ biomass ( $5.35 \mathrm{t} \mathrm{C} / \mathrm{ha}$ of canopy). In addition, preliminary soil $\mathrm{C}$ analyses have indicated that soil under currant bush canopy may contain up to $3 \mathrm{t} \mathrm{C/ha}$ more soil $\mathrm{C}$ than the surrounding soil (S. Bray, unpubl. data).

A key question for beef businesses in northern Australia and policy makers is whether positive greenhouse gas outcomes are consistent with positive economic and sustainability outcomes. Economic analysis of the Wambiana grazing trial using steers and bioeconomic modelling scaling up to a breeder finishing herd found that annual gross margins were highly variable in the HSR treatment with high returns in good seasons, but very poor or negative returns in poor seasons due to the market penalties on poor condition cattle, the high costs of drought feeding and interest on livestock capital (O'Reagain et al. 2011; O'Reagain and Bushell 2013; Scanlan et al. 2013). In contrast, annual gross margins in the MSR treatment were much more stable and over 12 years the accumulated gross margin was 1.7 times higher than the HSR treatment. Land condition was also far better in the MSR treatment (O'Reagain and Bushell 2013). The net $\mathrm{C}$ position analyses indicate that the MSR treatment had a better net $\mathrm{C}$ position than the HSR treatment (Fig. 3) supporting the notion that improved greenhouse gas emissions and positive net $\mathrm{C}$ position outcomes are consistent with economic and sustainability outcomes.

Significant climate variability is a feature of the northern grazing lands with significant annual, inter-annual and decadal variation (McKeon et al. 2009). Multi-year droughts and 'wet' periods impact $\mathrm{C}$ storage and emissions through the impact on forage production, land condition and livestock stocking rates (O'Reagain et al. 2011), tree growth (Back et al. 2009) and tree drought-induced die-back (Fensham and Holman 1999) and potentially soil C. The slow turnover of soil C (Krull et al. 2007) means that extreme events that only last a couple of years are likely to have a relatively minor impact. The most significant impact on $\mathrm{C}$ stock size and dynamics is the change in live woody vegetation that occurs in response to fire and drought events. These large fluctuations mean that an assessment of the net $\mathrm{C}$ position is sensitive to the 'reference' date or 'baseline'. The present 16-year assessment contains multi-year wet and dry periods minimising but not eliminating the risk of erroneous interpretation. However, by comparing the two treatments, it can be concluded that the MSR treatment has a better net $\mathrm{C}$ position than the HSR treatment. 
This analysis was based on a comprehensive dataset from one site in Australia's northern grazing lands; however, the methods and findings are expected to be applicable across northern Australia and savanna landscapes around the world. Future work using biophysical modelling incorporating economics and $\mathrm{C}$, once verified at sites such as the Wambiana grazing trial (e.g. Scanlan et al. 2013; Doran-Browne et al. 2014), can then be used to test and demonstrate the multiple benefits of moderate stocking rates as opposed to heavy stocking rates at locations throughout the grazing lands.

\section{Conclusions}

The extensive beef industry in northern Australia creates significant livestock greenhouse gas emissions. However, livestock emissions are only one component of the $\mathrm{C}$ cycle in which grazing businesses operate. Livestock grazing also affects $\mathrm{C}$ stocks and fluxes in pasture, woody vegetation and soil through the consumption of forage and other landscape impacts like fire. The Wambiana grazing trial in northern Queensland provided the opportunity to assess the net $\mathrm{C}$ position (reported as $\mathrm{t} \mathrm{CO}_{2}-\mathrm{e}$ ) incorporating $\mathrm{C}$ stocks and greenhouse gas emissions of two grazing management strategies over a 16-year period. The results indicate that tree biomass and woody vegetation dynamics dominate the $\mathrm{C}$ stocks and fluxes in grazed savanna woodlands. Over the 16-year trial, both MSR and HSR treatments had a positive net $\mathrm{C}$ position with the MSR treatment having a better net $\mathrm{C}$ position (19 $\mathrm{t} \mathrm{CO}_{2}$-e per ha) than the HSR treatment ( $9 \mathrm{t} \mathrm{CO}_{2}$-e per ha) primarily due to lower livestock emissions and greater pasture biomass and soil $\mathrm{C}$. These results support previously published benefits of grazing at moderate stocking rates compared with heavy stocking rates on land condition, financial returns and reduced risk.

\section{References}

ABS (2014) 'Land management and farming in Australia, 2012-13.' Available at http://www.abs.gov.au/ausstats/abs@.nsf/mf/4627.0 [Verified 18 July 2014]

Allen DE, Pringle MJ, Bray S, Hall TJ, O'Reagain PO, Phelps D, Cobon DH, Bloesch PM, Dalal RC (2013) What determines soil organic carbon stocks in the grazing lands of north-eastern Australia? Soil Research 51, 695-706. doi:10.1071/SR13041

Back PV (2005) The impact of fire on population density and canopy area of currant bush (Carissa ovata) in central Queensland and its implications for grazed woodland management. Tropical Grasslands 39, 65-74.

Back PV, Anderson ER, Burrows WH, Kennedy MJJ, Carter JO (1997) 'TRAPS - transect recording and processing system.' (Department of Primary Industries: Rockhampton, Qld)

Back PV, Anderson ER, Burrows WH, Playford C (2009) Research note: poplar box (Eucalyptus populnea) growth rates in thinned and intact woodlands in central Queensland. Tropical Grasslands 43, 188-190.

Bastin G (2008) 'Rangelands 2008. Taking the pulse.' (ACRIS Management Committee, National Land and Water Resources Audit: Canberra)

Bray SG, Golden R (2009) Scenario analysis of alternative vegetation management options on the greenhouse gas budget of two grazing businesses in north eastern Australia. The Rangeland Journal 31, 137-142. doi:10.1071/RJ08055

Bray S, Willcocks J (2009) 'Net carbon position of the Queensland beef industry.' (Department of Employment, Economic Development and Innovation: Brisbane Qld)
Bray SG, Krull ES, Harms BP, Baxter N, Rutherford M, Yee M, Cogle L (2006) Assessment of vegetation change in the Burdekin Catchment of Queensland - project report. No. QI06091. Department of Primary Industries and Fisheries, Rockhampton, Qld.

Bray SG, Liedloff AC, Sim AK, Back PV, Cook GD, Hoffmann MB (2007) Comparison of woody vegetation change datasets from the grazed woodlands of central Queensland, Northern Beef Research Update Conference, Townsville. (Eds B Pattie, B Restall) pp. 70-77. (North Australia Beef Research Council: Park Ridge, Qld)

Bray S, Harms B, Fraser G, Rutherford M (2010) Assessment of soil carbon stocks in response to land condition in Queensland's northern grazing land: Appendix A. In 'Keys to healthy savanna lands. Final report'. (Ed. K Broad) pp. 21-47. (Department of Employment, Economic Development and Innovation: Kairi, Qld)

Burrows WH, Henry BK, Back PV, Hoffmann MB, Tait LJ, Anderson ER, Menke N, Danaher T, Carter JO, McKeon GM (2002) Growth and carbon stock change in eucalypt woodlands in northeast Australia: ecological and greenhouse sink implications. Global Change Biology 8, 769-784. doi:10.1046/j.1365-2486.2002.00515.x

Charmley E, Stephens ML, Kennedy PM (2008) Predicting livestock productivity and methane emissions in northern Australia: development of a bio-economic modelling approach. Australian Journal of Experimental Agriculture 48, 109-113. doi:10.1071/EA07264

Cullen BR, Timms M, Eckard R, Mitchell RA, Whip P, Phelps D (2013) The effect of earlier mating and improving fertility on emissions intensity of beef production in a northern Australian herd. In 'Proceedings of the 5th international greenhouse gas and animal agriculture conference (GGAA 2013). 23-26 June 2013, Dublin, Ireland'. Advances in Animal Biosciences Vol. 4, Part 2. p. 403. (Cambridge University Press)

DAFF (2012) Blanncourt Station - productivity and profitability gains through efficient herd management. Available at http://futurebeef.com. au/wp-content/uploads/Blanncourt_CS_web.pdf [Verified 29 May 2014]

DIICCSRTE (2013) Australian national greenhouse accounts. National Inventory Report 2011. Department of Industry, Innovation, Climate Change, Science, Research and Tertiary Education, Canberra. Available at http://www.climatechange.gov.au/sites/climatechange/ files/documents/05_2013/AUS_NIR_2011_Vol1.pdf [Verified 6 September 2014]

Doran-Browne NA, Bray SG, Johnson IR, O'Reagain PJ, Eckard RJ (2014) Northern Australian pasture and beef systems. 2. Validation and use of the Sustainable Grazing Systems (SGS) whole-farm biophysical model. Animal Production Science 54, 1995-2002. doi:10.1071/AN14569

Eady S, Viner J, MacDonnell J (2011) On-farm greenhouse gas emissions and water use: case studies in the Queensland beef industry. Animal Production Science 51, 667-681. doi:10.1071/AN11030

Fensham RJ, Holman JE (1999) Temporal and spatial patterns in drought-related tree dieback in Australian savanna. Journal of Applied Ecology 36, 1035-1050. doi:10.1046/j.1365-2664.1999.00460.x

Fensham RJ, Low Choy SJ, Fairfax RJ, Cavallaro PC (2003) Modelling trends in woody vegetation structure in semi-arid Australia as determined from aerial photography. Journal of Environmental Management 68, 421-436. doi:10.1016/S0301-4797(03)00111-7

Garnett T (2009) Livestock-related greenhouse gas emissions: impacts and options for policy makers. Environmental Science \& Policy 12, 491-503. doi:10.1016/j.envsci.2009.01.006

Grice AC, Radford IJ, Abbott BN (2000) Regional and landscape-scale patterns of shrub invasion in tropical savannas. Biological Invasions 2, 187-205. doi:10.1023/A:1010021515356

Grosenbaugh LR (1952) Plotless timber estimates - new, fast, easy. Journal of Forestry 50, 32-37.

Hristov AN, Ott T, Tricarico J, Rotz A, Waghorn G, Adesogan A, Dijkstra J, Montes F, Oh J, Kebreab E, Oosting SJ, Gerber PJ, Henderson B, Makkar 
HPS, Firkins JL (2013) SPECIAL TOPICS - Mitigation of methane and nitrous oxide emissions from animal operations: III. A review of animal management mitigation options. Journal of Animal Science 91, 5095-5113. doi:10.2527/jas.2013-6585

Johnson KA, Johnson DE (1995) Methane emissions from cattle. Journal of Animal Science 73, 2483-2492.

Krull EG, Bray SS (2005) Assessment of vegetation change and landscape variability by using stable carbon isotopes of soil organic matter. Australian Journal of Botany 53, 651-661. doi:10.1071/BT04124

Krull E, Bray S, Harms B, Baxter N, Bol R, Farquher G (2007) Development of a stable isotope index to assess decadal-scale vegetation change and application to woodlands of the Burdekin catchment, Australia. Global Change Biology 13, 1455-1468. doi:10.1111/j.1365-2486.2007.01376.x

McKeon GM, Stone GS, Syktus JI, Carter JO, Flood NR, Ahrens DG, Bruget DN, Chilcott CR, Cobon DH, Cowley RA, Crimp SJ, Fraser GW, Howden SM, Johnston PW, Ryan JG, Stokes CJ, Day KA (2009) Climate change impacts on northern Australian rangeland livestock carrying capacity: a review of issues. The Rangeland Journal 31, 1-29. doi:10.1071/RJ08068

McLean I, Holmes P, Counsell D (2014) The northern beef report 2013. Northern beef situation analysis. Meat and Livestock Australia, Sydney.

MLA (2013) 'Australia's beef industry - fast facts 2013.' Available at http:// www.mla.com.au/Cattle-sheep-and-goat-industries/Industry-overview/ Cattle [Verified 22 May 2014]

O'Reagain P, Bushell J (2013) Managing for a variable environment: long term results from the Wambiana grazing trial. In 'Proceedings of the northern beef research update conference, Cairns. 12-15 August, 2013'. (Eds E Charmley, I Watson) pp. 55-60. (The North Australia Beef Research Council: Cairns, Qld)

O'Reagain P, Bushell J, Holloway C, Reid A (2009) Managing for rainfall variability: effect of grazing strategy on cattle production in a dry tropical savanna. Animal Production Science 49, 85-99. doi:10.1071/ EA07187

O'Reagain P, Bushell J, Holmes B (2011) Managing for rainfall variability: long-term profitability of different grazing strategies in a northern Australian tropical savanna. Animal Production Science 51, 210-224. doi:10.1071/AN10106

Pringle MJ, Allen DE, Dalal RC, Payne JE, Mayer DG, O'Reagain P, Marchant BP (2011) Soil carbon stock in the tropical rangelands of Australia: effects of soil type and grazing pressure, and determination of sampling requirement. Geoderma 167-168, 261-273. doi:10.1016/ j.geoderma.2011.09.001

Queensland Government (2013) 'Reef water quality protection plan 2013. Queensland.' Available at http://www.reefplan.qld.gov.au/resources/ assets/reef-plan-2013.pdf [Verified 5 September 2014]

Rolfe J (2010) Economics of reducing methane emissions from beef cattle in extensive grazing systems in Queensland. The Rangeland Journal 32, 197-204. doi:10.1071/RJ09026

Scanlan JC, MacLeod ND, O'Reagain PJ (2013) Scaling results up from a plot and paddock scale to a property - a case study from a long-term grazing experiment in northern Australia. The Rangeland Journal 35, 193-200. doi:10.1071/RJ12084

Segoli M, Bray S, Allen D, Dalal R, Watson I, Ash A, O’Reagain P (2014) Managing cattle for sustainable soil properties: interactions between stocking rates and rainfall. In 'Soil change matters'. Bendigo, Victoria, Australia'. pp. 139-143. (Ed. Department of Environment and PrimaryIndustries, Victoria)

Tothill JC, Hargreaves JNG, Jones RM, McDonald CK (1992) BOTANAL a comprehensive sampling and computing procedure for estimating pasture yield and composition. 1. Field sampling. Tropical Agronomy Technical Memorandum $\mathbf{7 8}$. 